\title{
Komunikasi Politik dan Partisipasi Warga dalam Arena Perencanaan dan Penganggaran Dana Keistimewaan DIY
}

\author{
Iranda Yudhatama \\ Mahasiswa Program Studi Magister Ilmu Komunikasi UNS \\ Jl. Ir Sutami No 36 A Surakarta \\ Email: yudha_merapi@yahoo.com
}

\begin{abstract}
As specialty province, Yogyakarta was given fives specialty authorities from government that encompass as following as: (1) procedures of occupation and authorities requirement for governor and vice governor; (2) Province government institutions; (3) Culture; (4) Land and (5) Space Policy. To prevail these, DIY government get the expenditure aid ftom central government. Some of studies showed that decentralization give people's participation more open. But on otherwise, some of studies also exposed that decentralization created democracy defisit. By qualitative approach, this research was aimed to elaborate political communication and people's participation in creating a plan and expenditure for DIY government in 2015. The results pointed out as: (1) political communication that was formed between government and people tended more linear or top down; (2) people's participation was a limited level; (3) people perception that the King will take step for people more responsible. These implied that all program was prevailing and initiating by government.
\end{abstract}

Keywords: political communication, planning, expenditure, participation and DIY

Abstrak

Sebagai daerah istimewa, Yogyakarta diberikan lima kewenangan khusus yang mencakup; (1) Tata cara pengisian jabatan, dan wewenang Gubernur dan Wakil Gubernur; (2) Kelembagaan Pemerintah Daerah; (3) Kebudayaan; (4) Pertanahan; dan (5) Tata Ruang. Untuk menjalankan lima kewenangan tersebut Pemerintah DIY mendapatkan pendanaan dari pemerintah pusat. Beberapa studi menunjukkan bahwa desentralisasi memberikan ruang dan partisipasi warga lebih besar. Namun di sisi lain beberapa studi juga menunjukkan gejala terjadinya defisit demokrasi. Dengan menggunakan metode kualitatif, penelitian ini bertujuan mengelaborasi komunikasi politik dan partisipasi warga dalam proses perencanaan dan penganggaran anggaran keistimewaan DIY tahun 2015. Hasil penelitian menunjukkan yakni: (1) Komunikasi politik yang terbangun antara pemerintah Propinsi dengan warga bersifat top down dan teknokratis; (2) Partisipasi warga relatif minim yang dikarenakan adanya kebijakan yang tidak membuka ruang partisipasi; (3) Persepsi bahwa warga tidak perlu berpartisipasi dalam perencanaan dan penganggaran karena yakin dengan kearifan Sultan selaku gubernur DIY. Dampak dari hal tersebut adalah sebagian besar program yang bersumber dari APBN diinisiasi dan dipimpin Pemerintah DIY dan cenderung menegasikan aspirasi warga.

Kata Kunci: Komunikasi politik, perencanaan, penganggaran, partisipasi warga, DIY 


\section{Pendahuluan}

Desentralisasi dalam pandangan mazhab Anglo Saxon sebagaimana yang dikemukakan oleh Sutoro Eko pada prinsipnya bertujuan untuk mendekatkan proses demokrasi ke aras lokal. Artinya proses desentralisasi tidak sekedar membagi dan menyerahkan kekuasaan, kewenangan dan keuangan pemerintah pusat kepada daerah tapi lebih dari itu adalah bagaimana mendorong proses demokratisasi pada aras lokal dan mendekatkan negara kepada rakyat sehingga berdampak bagi kesejahteraan masyarakat di daerah (Eko, 2013).

Namun sayangnya, dalam praktek desentralisasi dan otonomi daerah yang telah berjalan lebih dari satu dasawarsa di Indonesia ini, justru sebagian besar telah gagal memenuhi harapan terkait demokratisasi, mendekatkan pelayanan negara yang lebih baik kepada rakyat serta mewujudkan kesejahteraan rakyat pada aras lokal.

Banyak hasil riset dan kajian yang menunjukkan kegagalan sistem desentralisasi dan otonomi daerah dalam memenuhi harapan tersebut dan bahkan memunculkan fenomema anti demokrasi atau defisit demokrasi dalam bentuk patologi sosial yang akut dan kronis. Salah satu yang hasil studi yang paling populer dalam mengungkap kegagalan praktek desentralisasi dan otonomi daerah adalah studi Vedi Hadiz dalam Sutoro Eko. Hadiz memaparkan bahwa desentralisasi dan otonomi daerah telah memunculkan elit predator yang memanfaatkan daerah sebagai lahan kekuasaan baru bagi praktek-praktek kotor untuk melakukan korupsi dan premanisme politik di tingkat daerah.

Konsep elit predator ini juga serupa dengan konsep "local boss"atau orang kuat lokal yang dikemukakan oleh John Sidel dalam Sutoro Eko. Menurut Sidel, bos lokal merupakan tokoh-tokoh individu yang berpengaruh dan mempunyai kekuasaan untuk mengontrol atas sarana-sarana kekerasan, sumberdaya ekonomi dan mesin politik (Eko, 2013)

Demikian pula hasil studi yang dilakukan oleh Norholdt dan Haris (2004), Stokke dan
Tornuist (2004) dalam Pratikno yang menjelaskan bahwa terjadinya fenomena-fenomena non demokrasi dalam era desentralisasi dan otonomi daerah tersebut merupakan sesuatu yang telah berakar jauh di masa lalu dan diformulasikan oleh Nordholt sebagai fenomena "strong continuities of patrimonial patterns" atau meminjam terminologi Haris disebut sebagai"changing continuities" (Pratikno, 2010).

Pada perkembangannya kritik terhadap praktek-praktek desentralisasi dan otonomi daerah ini telah beranjak dari kritik terhadap implementasi (delivery sistem) beralih kepada kritik terhadap desain atau konsep desentralisasi yang bercorak simetris dan uniformitas yang selama ini diasumsikan paling ideal yang dituangkan dalam bentuk kebijakan Undangundang Nomor 32 tahun 2004.

Cara pandang atau paradigma simetris atau uniformitas ini menegasikan fakta keberagaman (pluralitas) dari setiap daerah di Indonesia dan praktek penyebaran kekuasaan melalui desentralisasi diimplementasikan secara seragam bagi seluruh daerah tanpa mempertimbangkan perbedaan fundamental, karakter dan kekhususan setiap daerah.

Beranjak dari konteks tersebut, beberapa kalangan intelektual dan aktivis yang peduli dengan perkembangan demokrasi pada aras lokal, mencoba menawarkan gagasan atau paradigma baru yang berseberangan dengan paradigma simetris. Cara pandang yang menekankan pada pentingnya desentralisasi kekuasaan yang memperhatikan keberagaman dan keunikan setiap daerah atau yang dikenal dengan desentralisasi asimetris (asymetrical desentralization) yang merupakan pemberlakuan kewenangan khusus atau otonomi khusus pada wilayah-wilayah tertentu dalam suatu negara (Pratikno, 2010) .

Hanya sayangnya, sejauh ini studi atau kajian terkait praktek desentralisasi asimetris relatif belumlah terlalu banyak dibandingkan dengan kajian tentang praktek-praktek desentralisasi simetris. Beberapa kajian atau studi desentralisasi asimetris yang adapun relatif 
mengkaji dari aspek kewenangan, keuangan, kontrol dan kelembagaan dalam konteks relasi hubungan pusat dan daerah. Seperti studi yang dilakukan oleh Pratikno, dkk yang lebih membahas terkait kewenangan, keuangan dan kelembagaan dalam praktek dan proyeksi desentralisasi asimetris di Indonesia.

Sementara kajian atau studi terkait dengan bagaimana komunikasi politik yang terbangun antara pemerintah daerah dengan warga dan bagaimana partisipasi warga yang berjalan dalam arena formulasi kebijakan saat implementasi desentralisasi asimetris diterapkan relatif belum tersedia.

Komunikasi politik merupakan sebuah studi yang multi disiplin ilmu, terutama dalam kaitannya antara proses komunikasi dan proses politik. Dalam konteks politik mengacu pada pendapat Graceau dalam Dan Nimmo, proses politik merupakan pola interaksi yang menghubungkan antara warga negara dengan pembuat keputusan baik dalam konteks, kesetaraan, kerjasama ataupun dalam konteks konflik (Nimmo, 1993). Hal ini dapat dimaknai bahwa pola interaksi antara warga negara dengan pemerintah dalam suatu arena kebijakan merupakan sebuah proses komunikasi dalam konteks politik. Sedangkan menurut Alfian dalam bukunya Komunikasi Politik dan Sistem Politik (1993), komunikasi politik merupakan bagian dari sistem politik yang mengkonversikan aspirasi dan kepentingan para pihak menjadi berbagai kebijakan.

Pola komunikasi politik sangat tergantung dari sistem politik yang dibangun dalam suatu masyarakat. Ada dua model pola komunikasi politik yang biasa dikenal dalam kajian komunikasi politik yakni, (1) Pola komunikasi politik horizontal, di mana posisi pelaku komunikasi yang terlibat dalam proses komunikasi politik relatif setara dan seimbang sehingga terjadi sharing atau saling berbagi informasi atau dialogis, bentuk atau pola komunikasi politik semacam ini hanya dapat terjadi dalam sebuah sistem politik yang demokratis; (2) Pola komunikasi politik yang berbentuk vertikal atau top down dan arus komunikasi cenderung satu arah menujukkan sistem politik yang merefleksikan nilai-nilai budaya feodalistik dan pola kepeminpinan yang totaliter (Panuju, 1994).

Berpijak dari teori dan konsep komunikasi politik tersebut, dapat diartikan bahwa komunikasi politik merupakan sebuah proses interaksi antara warga dengan negara (pemerintah) sebagai pelaku komunikasi pada suatu sistem politik baik dalam konteks agenda setting kebijakan, formulasi, implementasi maupun evaluasi kebijakan. Teori dan konsep inilah yang dijadikan perspektif dalam mengkaji pola komunikasi politik antara warga di satu sisi dan Pemerintah DIY di sisi lain sebagai pelaku atau aktor komunikasi politik dalam arena kebijakan perencanaan dan penganggaran anggaran keistimewaan DIY.

Demikian pula dengan tingkat partisipasi warga dalam sebuah sistem politik sangat ditentukan oleh pola komunikasi politik yang ada. Hal ini dapat diartikan bahwa semakin horisontal pola komunikasi politik dalam sebuah sistem politik maka akan semakin tinggi tingkat partisipasi warga. Sebaliknya semakin vertikal pola komunikasi politik dalam sebuah sistem politik maka akan semakin rendah tingkat partisipasi warga atau bahkan dapat menjadi apatis dan dapat menimbulkan feedback yang negatif dalam bentuk berkurangnya partisipasi politik formal dan merebaknya aktivitas politik "bawah tanah" atau aksi-aksi protes (Panuju, 1994).

Sementara itu, partisipasi sendiri tidak hanya dimaknai sekedar mengundang masyarakat (invited space) dalam sebuah proses formulasi kebijakan tapi lebih jauh dari itu yakni melibatkan masyarakat sipil dalam setiap tahapan partisipasi mulai dari mengidentifikasikan kebutuhan, perencanaan, implementasi sampai proses monitoring dan evaluasi sebuah kebijakan pembangunan (Chambers, 1996).

Berangkat dari nalar tersebut penelitian ini diletakkan, di mana penelitian ini merupakan bagian dari program riset-advokasi terhadap 
kebijakan perencanaan dan penganggaran anggaran Keistimewaan DIY yang dilakukan peneliti yang di dukung oleh Swara Nusa Institute dan Yayasan Tifa pada tahun 2015. Berpijak dari hal tersebut di atas, penelitian ini meneliti bagaimana partisipasi warga dan pola komunikasi politik yang berjalan dalam arena perencanaan dan penganggaran Dana Keistimewaan DIY sebagai sebuah arena formulasi kebijakan.

Pertanyaan kunci yang dikaji dalam penelitian ini adalah: (1) Bagaimana pola komunikasi politik antara warga dan Pemerintah DIY yang berjalan dalam arena perencanaan dan penganggaran Dana Keistimewaan DIY tersebut?; (2)Bagaimana partisipasi warga dalam arena perencanaan dan penganggaran Dana Keistimewaan DIY?

\section{Metode Penelitian}

Berangkat dari kerangka pikir dan permasalahan di atas, jenis penelitian yang digunakan adalah penelitian kualitatif. Hal ini dikarenakan proses perencanaan dan penganggaran Dana Keistimewaan DIY dimaknai sebagai proses interaksi dialektis antara aktor negara dan warga masyarakat. Interaksi dialektis adalah realitas kehidupan sosial yang dinamis, sehingga lebih tepat dikaji secara kualitatif dibandingkan secara kuantitatif dengan mengandalkan angka statistik, (Giddens, 1984). Metode penelitian kualitatif pun dapat memberi jalan bagi peneliti untuk mengeksplorasi secara mendalam terhadap perpektif, pengetahuan dan praktik sosial para informannya (Flick, 1998).

Metode kualitatif yang dipilih adalah studi kasus. Studi kasus dipilih karena relevan dengan tema kajian yang tengah menyelidiki suatu proses, aktivitas dan peristiwa yang dibatasi oleh waktu dan aktivitas (Creswell, 2010), terkait pola komunikasi politik dan partisipasi warga dalam arena perencanaan dan penganggaran Dana Keisitmewaan DIY tahun 2015.

\section{Hasil Penelitian dan Pembahasan}

Peraturan yang mengatur tentang Dana Keistimewaan bersumber dari Undang-undang
No.13 Tahun 2012 tentang Keistimewaan DIY. Secara prinsip pasal-pasal tersebut menyatakan bahwa pemerintah menyediakan pendanaan dalam rangka penyelenggaraan urusan Keistimewaan DIY dalam Anggaran Pendapatan dan Belanja Negara sesuai dengan kebutuhan DIY dan kemampuan keuangan negara. Dana dalam rangka pelaksanaan Keistimewaan Pemerintahan Daerah DIY tersebut dibahas dan ditetapkan oleh Pemerintah berdasarkan pengajuan Pemerintah Daerah DIY .yang diperuntukkan dan dikelola oleh Pemerintah Daerah DIY yang pengalokasian dan penyalurannya melalui mekanisme transfer ke daerah.

Ada pun penjabaran dari undang-undang tersebut terkait dengan Dana Keistimewaan dituangkan dalam Peraturan Daerah Istimewa (Induk) No. 1 Tahun 20 tentang yang menyatakan dalam rangka pelaksanaan urusan Keistimewaan, Pemerintah Daerah wajib membuat rencana kebutuhan yang dituangkan dalam rencana program dan kegiatan tahunan dan 5 (lima) tahunan. Peraturan daerah ini diturunkan lagi dalam bentuk peraturan teknis berupa Peraturan Gubernur (Pergub) Nomor 37 tahun 2014 tentang Pengelolaan Dana Keisitmewaan yang tidak mengatur secara jelas dan detil terkait mekanisme partisipasi warga dalam proses formulasi kebijakan perencanaan dan penganggaran Keistimewaan DIY.

Hasil penelitian terkait pola komunikasi politik dan partisipasi warga dalam arena perencanaan dan penganggaran Dana Keistimewaan DIY menemukan beberapa hal menarik, antara lain; (1) Pola komunikasi politik yang terbangun antara warga DIY di satu sisi dengan pemerintah DIY dalam arena kebijakan tersebut membentuk pola vertikal, top-down, satu arah dan cenderung teknokratis; (2) Pola komunikasi vertikal tersebut menjadikan tidak adanya partisipasi warga dalamarenaperencanaan dan penganggaran Dana Keisitimewaan DIY tersebut.

Beberapa forum perencanaan dan penganggaran Dana Keistimewaan DIY yang diikuti peneliti di tingkat Propinsi DIY yang 
diselenggarakan oleh Bappeda DIY, meskipun mengundang perwakilan warga hanya cenderung untuk mensosialisasikan dan melegitimasi usulan agenda kegiatan yang telah disusun oleh pihak pemerintah DIY. Posisi warga hanya sebagai peserta forum tersebut.

Ada beberapa faktor yang menyebabkan munculnya pola komunikasi politik vertikal, topdown, satu arah dan teknokratis tersebut, salah satunya adalah adanya kebijakan teknis dalam bentuk Peraturan Gubernur Nomor 37 tahun 2014 tentang Pengelolaan Dana Keisitmewaan DIY yang tidak mencantumkan secara eksplisit ruang dan mekanisme partisipasi warga dalam arena perencanaan dan penganggaran Dana Keistimewaan DIY tersebut.

Hal ini sebagaimana pernyataaan dari pihak Pemerintah DIY melalui Bambang Wisnu Handoyo selaku Kepala DPPKA DIY (Dinas Pendapatan, Pengelolaan Keuangan dan Aset) dan juga Sulistyo selaku Assisten tiga bidang kesejahteraan sosial Pemda DIY dalam sebuah wawancara dan fokus grup diskusi. Mereka berdua mengakui bahwa meskipun saat ini Pemerintah DIY tengah menuju kepada penggunaan paradigma governance dan bukan goverment dalam tata kelola pemerintahan, yang artinya pemerintah harus lebih responsif dan melibatkan partisipasi masyarakat sebagai stake holder pembangunan tetapi dalam konteks implementasi Dana Keistimewaan diakuinya belum mampu menjalankan secara optimal. Persoalan ini dapat diartikan bahwa ada setting kebijakan yang dengan sengaja membuat pola komunikasi politik menjadi vertikal (top down) atau linier. Peraturan Gubernur No.37 Tahun 2014 tentang Pengelolaan Dana Keistimewaan tidak memberikan ruang bagi artikulasi politik warga.

Situasi dan kondisi ini semakin diperparah dengan masih adanya pandangan dari sebagian warga di DIY selaku informan penelitian yang hadir dalam suatu forum perencanaan dan penganggaran Dana Keisitmewaan DIY yang memandang bahwa permasalahan Dana Keistimewaan adalah kewenangan dari pihak
Pemerintah DIY dan bukan kewenangan mereka selaku warga negara sehingga mereka merasa tidak perlu ikut campur atau ribut-ribut untuk terlibat dalam proses perencanaan dan penganggaran Dana Keistimewaan DIY. Hal ini terutama disebabkan oleh faktor nilai dan keyakinan serta latar belakang budaya informan tersebut.

Sebagaimana mengutip pendapat Nimmo, bahwa warga negara sebagai individu selalu membuat pilihan untuk berpartisipasi atau tidak dalam suatu aktivitas politik melalui proses intepretatif yang dipengaruhi oleh nilainilai, keyakinan dan latar belakang budaya yang membingkainya dalam suatu proses komunikasi politik (Nimmo, 1993).

Pendapat Nimmo tersebut, sangat relevan jika dikontekstualisasikan dengan bagaimana warga Yogyakarta sebagai individu mengintepretasikan atau memaknai Kebijakan Keistimewaan DIY terutama dalam kaitannya dengan keterlibatan mereka dalam proses perencanaan dan penganggaran Dana Keistimewaan DIY sebagai sebuah aktivitas politik. Proses pengintepretasian atau pemaknaan ini juga sangat mempengaruhi bagaimana perspektif atau cara pandang warga Yogyakarta dalam memaknai relasi politik antara mereka sebagai warga negara dan sekaligus bagian dari masyarakat sipil dengan pihak pemerintah DIY (negara) selaku pembuat kebijakan. Hal ini dapat diartikan, bahwa keputusan politik warga Yogyakarta untuk berpartisipasi atau tidak berpartisipasi dalam proses perencanaan dan penganggaran Dana Keistimewaan DIY sebagai proses politik sangat tergantung dari nilai-nilai, keyakinan dan latar belakang budaya mereka.

Pemaknaan atau intepretasi atas tersebut dapat tercermin dari ungkapan-ungkapan warga yang muncul dalam serangkaian aktivitas wawancara dan fokus grup diskusi selama penelitian berlangsung. Sebagai contoh, apa yang diungkapkan oleh seorang aktivis perempuan yang bernama Anik dari organisasi perempuan Srikandi Mataram yang hadir dalam sebuah forum perencanaan dan penganggaran 
Dana Keistimewaan yang menyatakan bahwa selaku warga Yogyakarta tidak akan menuntut apa-apa dari Dana Keistimewaan DIY, karena perjuangan mereka adalah ikhlas untuk mengusung penetapan Ngarso Dalem menjadi gubernur DIY dan yang penting bagi Anik dan organisasi Srikandi Mataram adalah dengan adanya Undang-undang Keistimewaan, Sultan memiliki posisi yang jelas selaku kepala daerah dan kepala pemerintahan DIY. Bagi Anik dan rekan-rekanya di Srikandi Mataram masalah Dana Keistimewaan DIY bukanlah kewenangan atau urusan mereka, tetapi merupakan urusan Pemerintah DIY dan mereka yakin betul bahwa pasti Ngarso Dalem selaku gubernur akan memikirkan yang terbaik bagi kesejahteraan rakyatnya.

Pendapat yang senada juga dikemukakan oleh Mangun selaku warga Kabupaten Kulon Progo dan aktif selaku penghayat kepercayaan. Menurutnya bagi orang Jawa khususnya warga Yogyakarta, percaya bahwa Ngarso Dalem sebagai seorang raja dan sekaligus gubernur pasti memiliki kearifan seorang raja dalam memikirkan rakyatnya. Lebih lanjut Mangun mengatakan bahwa masalah urusan terkait kebijakan Dana Keistimewaan merupakan urusan pihak Pemerintah DIY yang di bawah kepemimpinan Sri Sultan Hamengku Buwono $\mathrm{X}$ pasti akan memikirkan secara bijaksana dan yang terbaik bagi rakyat atau kawulonya.

Halyang samajuga diungkapkan beberapa informan lainnya, seperti Sukijan, Martadani, Sudarman, Supri Indrajit yang menyatakan bahwa keistimewaan DIY adalah terletak pada kepemimpinannya yang arif dan bijaksana yakni Sri Sultan HB X sehingga pastilah Sri Sultan HB $\mathrm{X}$ yang sekaligus Guburnur DIY akan membuat kebijakan anggaran keistimewaan dengan menggunakan kearifan dan kebijaksanaannya demi kesejahteraan warga DIY.

Secara substansi apa yang diungkapkan baik oleh Anik, Mangun, Sukijan, Sudarman, Supri Indrajit maupun Martadani mencerminkan atau merefleksikan pemaknaan mereka terhadap praktek desentralisasi asimetris DIY dalam konteks perencanaan dan penganggaran Dana Keistimewaan. Ungkapan-ungkapan ini dapat dimaknai bahwa, masih ada sebagian dari warga Yogyakarta baik yang tinggal di perkotaan maupun pedesaan, baik yang berpendidikan tinggi maupun tidak yang mengintepretasikan atau memaknai urusan atau kewenangan Keistimewaan DIY termasuk di dalamnya Dana Keistimewaan merupakan kewenangan dari Pemerintah DIY dan percaya bahwa dengan kearifan seorang raja yang dimanifestasikan melalui personifikasi Sri Sultan Hamengku Buwono X akan dapat memikirkan kesejahteraan rakyatnya sebagai kawulo atau dengan kata lain mereka sebagai warga mengintepretasikan bahwa partisipasi dalam konteks perencanaan dan penganggaran Dana Keistimewaan tidaklah perlu dan bukan kewenangan mereka karena mereka percaya bahwa Kasultanan sebagai sebuah institusi yang merupakan sentral dari politik, ekonomi dan budaya akan mampu memikirkan yang terbaik untuk kesejahteraan rakyat.

Cara pandang demikian muncul karena memang secara sosio-psikologis dan sosio kultural masih ada sebagian corak masyarakat di DIY yang memiliki karakter patron-client yang kuat dan disertai dengan kepercayaan terhadap mitos dan hal-hal yang berbau mistis sebagaimana yang tertuang dalam studi Nur Azizah (2010). Menurutnya karakter ini dapat diidentifikasi dari antusiasme masyarakat Yogyakarta yang masih kuat terhadap acaraacara ritual yang diselenggarakan oleh pihak Kraton untuk mendapatkan keberkahan atau dalam bahasa jawa disebut Ngalap Berkah. Dalam konteks ini dapat dikatakan bahwa masih relatif kuat posisi Kraton dan Pakualaman dalam ruang sosial budaya masyarakat yang diposisikan sebagai pusat budaya dan simbol pengayom.

Dukungan secara sosio psikologis dan sosio kultural terhadap Kraton yang direpresentasikan oleh raja Sri Sultan HB $\mathrm{X}$ ini sejatinya memiliki akar sosio historis yang kuat di Yogyakarta. Sebagaimana yang pernah diungkapkan oleh Selo Sumardjan 
dalam bukunya Perubahan Sosial di Yogyakarta (Sumardjan, 2009). Dalam bukunya tersebut, Sumardjan mengatakan bahwa kepercayaan atau keyakinan yang khas dari orang Jawa di Yogyakarta yakni, kepercayaan bahwa semua barang atau segala sesuatu yang baik berasal dari Sultan (raja). Oleh karenanya hampir semua barang atau benda diberi awalan raja. Sepeti sesuatu yang paling berharga bagi petani Jawa dinamakan rajakaya (kekayaan raja) dan barangbarang berharga seperti emas disebut rajapeni atau rajabrana (benda-benda berharga dari raja)

Berangkat dari konteks tersebut, dapat dikatakan bahwa pola komunikasi politik antara warga di satu sisi dengan pihak Pemerintah DIY yang direpresentasikan oleh seorang raja yang sekaligus seorang gubernur akan cenderung berbentuk vertikal atau hubungan atas-bawah. Akibatnya jelas, komunikasi politik yang terbentuk cenderung satu arah, arus informasi hanya berjalan satu arah dari Pemerintah DIY selaku pihak yang mendesain pesan kebijakan (komunikator/Sender) kepada masyarakat sipil selaku warga negara dan juga komunikan (reciever) dalam konteks komunikasi politik.

Masyarakat sebagai penerima manfaat kebijakan hanya diposisikan sebagai pihak komunikan (reciever) yang pasif dan relatif tidak diberi ruang dialog untuk mengintepretasikan, memahami dan mengartikulasikan pendapat, gagasan dan kepentingannya terkait program kegiatan yang bersumber dari Dana Keisitmewaan.

Hal ini membuat bentuk komunikasi yang terjadi membentuk pola vertikal (top down yang mendominasi proses komunikasi politik dalam konteks perencanaan dan penganggaran keistimewaan DIY. Aspirasi dan artikulasi warga menjadi ternegasikan tergantikan oleh kepentingan birokrasi pemerintah DIY.

Namun demikian tidak semua warga Yogyakarta berpendapat sama terkait hal tersebut. Beberapa warga Yogyakarta ada yang memiliki pendapat kritis terkait proses perencanaan dan penganggaran Dana Keistimewaan DIY yang terangkum dalam hasil wawancara dan diskusi.
Hal ini terungkap dalam serangkain proses wawancara dan diskusi yang bergulir selama penelitian ini. Salah satu informan penelitian ini, Imam Setyadi selaku warga kabupaten Bantul dan pegiat LSM mengatakan bahwa perencanaan dan penganggaran Dana Keistimewaan seharunya lebih trasparan dan partisipasit. Menurutnya jika hal ini dibiarkan terus berlanjut akan menjadi preseden buruk bagi DIY sebagai daerah Istimewa dan Imam khawatir jika status keistimewaan yang dimiliki oleh DIY ini justru akan menjadi tidak istimewa ketika anggaran keistimewaan yang ada tidak bermanfaat bagi masyarakat.

Pendapat lain yang menarik adalah pendapat yang diungkapkan oleh Wignyo selaku informan dan warga yang tinggal di bantaran Kali Code dan merupakan pengurus dari organisasi warga yang tinggal di bantaran sungai yang bernama Paku Bangsa. Menurutnya sebagai orang yang lahir di Yogyakarta dan menetap di Yogyakarta dan sampai sekarang masih tinggal di pinggiran sungai belum bisa merasakan perbedaan antara DIY sebagai wilayah yang istimewa dengan adanya undang-undang keistimewaan dengan Yogyakarta yang tidak istimewa. Menurutnya yang jauh lebih penting dalam berbicara Dana Keistimewaan adalah bagaimana dana yang bersumber dari APBN tersebut dapat memenuhi hak-hak masyarakat dengan melibatkan partisipasi warga karena baginya itu adalah hak rakyat bukan kebaikan hati penguasa.

Hal yang relatif sama juga dikatakan oleh Syarifudin, Mugiono, Imam Syafii, Suyanto yang menyatakan bahwa sudah saatnya Pemda DIY sekarang lebih membuka diri dan melibatkan partisipasi masyarakat secara lebih luas, sehingga ide-ide kreatif dan inovatif dalam menterjemahkan keistimewaan DIY dapat dijadikan masukkan dalam perencanaan dan penganggaran program keistimewaan DIY.

Penelitian ini menunjukkan bahwa ada sebagian warga yang memutuskan untuk tidak berpartisipasi dan tidak merasa mempunyai hak atas Dana Keistimewaan serta memaknai 
bahwa urusan atau kewenangan keistimewaan bukanlah urasan mereka tapi lebih merupakan kewenangan dari pihak Pemerintah DIY yang direpresentasikan oleh figus Sri Sultan Hamengkubuwo $\mathrm{X}$ sebagai seorang raja dan sekaligus gubernur yang mereka yakini pasti akan memikirkan kesejahteraan rakyatnya secara arif dan bijaksana.

Namun di sisi lain, ada juga sebagian warga yang memiliki cara pandang yang kritis dalam memaknai arena perencanaan dan penganggaran Dana Keistimewaan DIY sebagai sebuah arena demokrasi menginginkan bahwa relasi antara warga negara dengan negara sebagi bukan dalam relasi patron-client tapi sebuah relasi politik antara aktor dan struktur yang saling mempengaruhi atau bersifat dualitas dalam sebuah arena formulasi kebijakan perencanaan dan penganggaran.

Dalam konteks tersebut dengan meminjam teori strukturasi dari Giddens (Prijono, 2002), dapat dikatakan jika ruang partisipasi telah dihadirkan maka kapasitas untuk menjamin dan meningkatkan efektivitas partisipasi warga dan masyarakat sipil secara berkelanjutan akan tergantung pada interaksi dualitas antara agency atau aktor baik individual agency maupun collective agency dengan struktur yang mencakup tata nilai dan makna, kekuasaan, kebijakan dan sumber daya termasuk sumberdaya keuangan. Melalui proses interaksi inilah praktekpraktek sosial (social action) akan terjadi dan membuat struktur baru di Daerah Istimewa Yogyakarta terutama dalam konteks penguatan dan pelembagaan partisipasi guna mewujudkan kesejahteraan masyarakat.

\section{Simpulan}

Berpijak pada hasil temuan penelitian ini, ada beberapa catatan penting yang dapat disimpulkan terkait dengan pola komunikasi politik dan partisipasi warga dalam perencanaan dan penganggaran Dana Keistimewaan DIY tahun 2015. Pertama, dalam praktek atau implementasi desentralisasi asimetris DIY dalam konteks proses perencanaan dan penganggaran Dana Keistimewaan pola komunikasi politik antara warga di satu sisi dengan pihak Pemerintah DIY cenderung membentuk pola liniar dan vertikal atau hubungan atas-bawah. Hal ini dikarenakan adanya setting politik dalam bentuk kebijakan yang dengan sengaja membuat pola komunikasi politik menjadi vertikal (top down) atau linier. Peraturan Gubernur No.37 Tahun 2014 tentang Pengelolaan Dana Keistimewaan yang tidak memberikan ruang bagi artikulasi politik warga dan masyarakat sipil.

Kedua, situasi dan kondisi ini didukung dengan masih adanya pandangan dari sebagian warga masyarakat di DIY yang memandang bahwa permasalahan Dana Keistimewaan adalah kewenangan dari pihak Pemerintah DIY dan bukan kewenangan mereka selaku warga negara sehingga mereka merasa tidak perlu ikut campur atau ribut-ribut untuk terlibat dalam proses perencanaan dan penganggaran Dana Keistimewaan DIY.

Ketiga, dalam proses perencanaan dan penganggaran Dana Keistimewaan mengutamakan pendekatan teknokratis yang menegasikan pendekatan partisipatif dan yang terjadi adalah partisipasi semu yang dapat menjadi sebuah ancaman bagi bersemainya demokrasi. Sebab keputusan tidak menjadi domain kontrol publik tapi menjadi wilayah otoritas pemerintah dan elit politik, karena pada hakekatnya dinamika negoisasi antara warga negara dengan penyelenggara negara adalah jantung demokrasi.

Bentuk komunikasi politik ini disadari atau tidak pada akhirnya akan menciptakan situasi yang non demokratis dan bergeser menjadi feodalistik ketika relasi politik yang terbangun adalah relasi patron-client dan bukan relasi antara warga negara dan negara yang demokratis yang memberikan ruang partisipasi aktif bagi warganya untuk mengartikulasikan ide-ide, gagasan dan kepentingannya dalam sebuah ruang publik (public sphere). 
Dampak dari ke dua hal tersebut adalah hampir sebagian besar program kegiatan yang terkait dengan implementasi kewenangan Keistimewaa DIY yang dibiayai oleh Dana Keistimewaan DIY yang bersumber dari APBN didrive dan didirect oleh Pemerintah DIY dan cenderung menegasikan aspirasi warga

Berkaca dari temuan-temuan penelitian ini, perlu adanya perbaikan atas mekanisme proses perencanaan penganggaran yang memberikan ruang partisipasi secara maksimum bagi warga untuk terlibat aktif. Selain memberikan ruang partisipasi yang maksimum, hal lain yang penting adalah membangun pola komunikasi politik yang horisontal dalam proses formulasi kebijakan, di mana posisi antara warga di satu sisi dan Pemerintah DIY termasuk di dalamnya adalah posisi kelembagaan dari Kasultanan dan Puro Pakualaman yang relatif setara dan seimbang sehingga dapat berjalan proses dialogis dalam memaknai Keisitmewaan DIY yang dituangkan dalam bentuk formulasi kebijakan anggaran keistimewaan DIY. Dengan demikian warga dapat terlibat dalam perencanaan dan melakukan kontrol atau monitoring atas pelaksanaan kebijakan dan program keistimewaan DIY sehingga masyarakat dapat merasakan manfaat dari keistimewaan DIY. Berangkat dari nalar tersebut, dibutuhkan suatu terobosan terkait partisipasi masyarakat dalam proses perencanaan dan penganggaran dalam konteks Keistimewaan DIY? Secara khusus untuk mengembangkan ruang partisipasi warga DIY di dalam proses perencanaan daerah, dapat dilakukan langkah-langkah berikut ini :

1. Perlunya membuka ruang partisipasi warga secara maksimum dalam proses perencanaan dan pengangaran anggaran keistimewaan DIY melalui penyusunan Peraturan Gubernur terkait Perencanaan dan Penganggaran Keistimewaan DIY yang mencantumkan secara tegas dan jelas partisipasi warga dalam setiap tahapan perencanaan dan penganggaran Dana Keistimewaan DIY,
2. Dalam konteks relasi pemerintah DIY dengan warga, warga DIY harus dipandang sebagai warga (citizen). Perubahan cara pandang ini menjadi prasyarat bagi upaya memberdayakan mereka menjadi warga aktif (active citizen) di DIY. Sehingga bentuk komunikasi politik dalam konteks perencanaan dan penganggaran Keistimewaan DIY dapat berbentuk horisontal, artinya proses komunikasi politik yang dibangun akan semakin demokratis,

Sehingga perwujudan dari semangat desentralisasi asimetris DIY dapat dimaknasi sebuah proses demokratisasi pada aras lokal yang memberikan ruang bagi bersemainya demokrasi dan partisipasi warga dalam memaknai pembanguan Keistimewaan DIY . Sehingga jika hal itu yang terjadi warga tidak dilihat sebagai obyek penguasa namun warga atau masyarakat akan dilihat sebagai warga negara aktif (active citizen) untuk ikut berpartispasi dan menentukan nasibnya sendiri dalam rangka Keistimewaan DIY.

\section{Daftar Pustaka}

Alfian, 1993, Komunikasi Politik dan Sistem Politik, Jakarta: Gramedia Chambers. Robert, 1996, Participatory Rural Appraisal, Memahami Desa Secara Partisipatif, Yogyakarta: Pustaka Pelajar Creswell, John W., 2010, "Research Design, Pendekatan Kualitatif, Kuantitatif dan Mixed, Yogyakarta: Pustaka Pelajar Diamond, Larry, 2005,"Developing Democray, Toward Consolidation, NJ: IRE Press

Eko, Sutoro, 2013, Daerah Inklusif, Pembangunan Demokrasi Lokal dan Kesejahteraan, Yogyakarta: IRE Press Flick, Uwe, 1998, “An Introduction to Qualitative Research, London, Sage Publication Giddens, Anthony, 1984, The Construction of Society, The outline of The Theory of Structation, yang diterjamahkan 
oleh Adi Suyuno, 2003; Teori Strukturasi untuk Analisa Sosial, Pasuruan Jawa Timur: Penerbit Pedati Guillermo O’Donnell dan Philippe C. Schimiter, 1993, Transisi Menuju Demokrasi: Rangkaian Kemungkinan dan Ketidakpastian, Jakarta: LP3ES. Nimmo, Dan, 1993, Komunikasi Politik: Komunikator, Pesan dan Media, Bandung: Rosdakarya Panuju, Redi, 1994, Telaah Politik Untuk Studi Komunikasi, Surabaya: Lembaga Penerbitan Fakultas Komunikasi Unitomo. Pratikno dkk, 2010 Jurusan Politik dan Pemerintahan FISIP UGM, Desentralisasi Asimetris di Indonesia; Praktek dan Proyeksi, Yogyakarta
Priyono Herry B, 2002, Anthony Giddens, Suatu Pengantar, Jakarta: Gramedia Windlesham, Lord, 1972 "What is Political Communication" dalam K.J. McGarry (Ed.), Mass Communication, Linnet Books \& Clive Bingley. Undang-undang Nomor 13 Tahun 2012 Tentang Keistimewaan DIY Peraturan Daerah Istimewa Induk Nomor 1 Tahun 2013 tentang Kewenangan Dalam Urusan Keistimewaan DIY Peraturan GubernurNomor 37 Tahun 2014 tentang Pengelolaan Dana Keistimewaan DIY Badan Pusat Statistik, 2014 